\title{
POR QUEM OS SINOS DOBRAM: AS DIFICULDADES DA LINGUAGEM DAS REDAÇÕES NÃO ME SÃO ALHEIAS.
}

\author{
Suzi Frankl Sperber ${ }^{*}$
}

\begin{abstract}
[...] a morte de qualquer homem me diminui, porque sou parte da humanidade; e por isso, nunca procure saber por quem os sinos dobram, eles dobram por você. (DONNE, John, Meditation XVII $)^{1}$
\end{abstract}

\section{Introdução}

A leitura de redações produzidas por adultos (jovens de escolarização mais avançada - na minha experiência pessoal, a partir do segundo grau) esbarra na apreensão repetida de determinadas marcas. Seriam "erros". Estudos sobre redações indicam falta de coesão e utilização de estratégias de preenchimento. Esta observação corresponde. $\mathrm{O}$ uso da linguagem destas redações revela uma ideologia - e pressão. Em geral diz-se que os "erros" decorrem do uso inábil, desajeitado, da oralidade. A urgência de comunicar e os hábitos da fala do aluno seriam responsáveis pelo insucesso na escrita. Conheço, porém, a pressão exercida pelas mil caras do poder instituído - ou do poder dos grupos com os quais convivemos. Parcialmente, ela é absorvida como preconceito com respeito a si mesmo, por razões que parecem alheias à sociedade e de cunho psíquico pessoal. $\mathrm{O}$ grupo social de "respeito" constrói e mantém, difusamente, a mitologia do oprimido incompetente (até certo ponto pela ação do "mito burguês"²). O insucesso escolar decorreria da absorção, por parte do excluído, da mitologia construída sobre ele? E qual a relação entre o efeito de uma mitologia específica (ainda que abrangente) como essa, sobre a morfologia do mito?

Examinarei redações de alunos (sobretudo textos produzidos a partir da adolescência) para identificar certas marcas recorrentes. A maior parte dos textos foi solicitada por mim - enquanto professora - tanto em curso universitário $\left(1^{\circ}\right.$ semestre letivo), como em cursos de especialização para professores de $1^{\circ}$ e $2^{\circ}$ graus. Para $o$ trabalho a que me propunha, examinei também redações de alunos de $2^{\circ}, 3^{\circ}$ e $4^{\circ}$ séries do $1^{\circ}$ grau, assim como redações esparsas de alunos das séries seguintes ao $1^{\circ}$ grau (de

\footnotetext{
"Unicamp

${ }^{1}$ DONNE, John (Henry Alford, ed.). The Works of John Donne. vol III. London: John W. Parker, 1839. 574-5.

${ }^{2}$ Leia-se BARTHES, Roland. Mitologias. São Paulo: Cultrix, 1981.
} 
alunos considerados difíceis) e mesmo de alunos pré-universitários ${ }^{3}$. Reconheço que para fins estatísticos precisaria ter feito um levantamento rigoroso, uma contagem precisa, a fim de quantificar os dados. Mas o sistema rigoroso não acrescenta a não ser argumentos para o que se quer provar. E procuro respostas para o problema da produção precária de textos, para o que a análise de um conjunto de textos pode ser suficiente, a partir do momento em que a minha prática docente já permitiu um convívio bastante grande com o problema. Formularei hipóteses. É até bom que não se apresentem como verdades acabadas.

Notei que o avanço na escolarização produzia alguns efeitos deletérios comuns em textos, alunos e situações escolares diferentes. Quanto mais adiantado na escolarização o autor do texto, mais recorrentes eram fenômenos para os quais ainda não tinha nome, e que levavam à precariedade ou pobreza da expressão escrita. A minha primeira reação foi entristecer-me. A segunda, convencida de que um problema é apenas um desafio a ser solucionado, foi empreender a tarefa de analisar os textos para ver se encontraria tendências comuns entre os diferentes textos. Assim cheguei às características descritas abaixo, como a generalização; vagueza; dogmatismo; maniqueísmo; redundância; discurso filosofante; personificação do inanimado.

\section{Generalização.}

Para cada característica utilizarei um e só um texto, que transcreverei em nota.

O texto em nota ${ }^{4}$ contém três pronomes indefinidos: "ninguém", "ninguém" e "todos". O verbo "observar" é repetido três vezes (a terceira sob a forma de "capacidade de ver"). O primeiro verbo está no pretérito (observou) e os outros no presente (observa, perdemos e os seguintes). O passado se refere a uma situação de mudança do contexto

${ }^{3}$. Tenho trabalhos publicados a respeito In Língua e Literatura: o professor pede a palavra e no material de Tecnologia Educacional Aplicada ao Ensino de Português no $1^{\circ}$ Grau. Rio: ABT/FCBT/MEC, vol.4: (4. Ensinar a escrever. Marcas das pressões sociais nas redações. vol. IV. Rio de Janeiro: ABT, 1983.); e vol.9: (9. Análise de redações de alunos de $2^{a} a ̀ 4^{a}$ séries. vol. IX. Rio de Janeiro: ABT, 1985.)

$4 \quad$ Trajeto

Ninguém observou. Ninguém observa. Todos perdemos a capacidade de ver, empenhados que estamos em chegar depressa, voltar correndo. E para onde corremos, sem olhar para os lados?

O caminho não é apenas a nata de concreto escuro e sem fim ou a poeira que se levanta. Por que não olhar do lado? Pode haver uma paineira florida ostentando sua beleza contra um azul profundo. Ou o descampado pode estar verde, atravessado de matizes que pincel nenhum conseguirá reproduzir fielmente. Que ganhamos assimilando o trajeto de forma a caminhar por ele sem vê-lo? Estamos dentro de uma máquina. Ela se movimenta ligeiro. Não é possível caminhar a pé. Temos que chegar logo, voltar correndo. A paineira? Ah... sim, existe uma paineira... perdida num canto qualquer do caminho. 
narrado. Os verbos no presente generalizam. (O raciocínio subjacente à generalização seria mais ou menos assim: "Como não pude registrar aquele momento, como não me detive em observar o mundo que me cercava, chego à conclusão de que ninguém observa, isto é, de que posso generalizar para todas as pessoas, tempos e lugares aquilo que ocorreu uma vez"). A repetição reforça a generalização: "Todos perdemos a capacidade de ver". A "anestesia diante da realidade" é lugar comum. É sabedoria de Reader's Digest. Por que se apropriaria alguém de lugares comuns? O que seria lugar comum: a linguagem, o conteúdo, ou a generalização em si?

O procedimento generalizador opera de modo a que o particular passe a ter o valor de geral e absoluto. Aparentemente, por contaminação, o autor do texto pressupõe que aquilo sobre que ele fala é do conhecimento de todo mundo. Por isto dispensa caracterizar, não esclarece circunstâncias, não dá referências. A generalização atinge mais do que só alguns termos e o uso de tempo verbal.

Generalizado, o relato não questiona aquilo sobre o qual fala. A causalidade é encoberta pelo já lugar comum determinista, resignado e estigmatizador de que as coisas são como são por natureza, irreversível e definitivamente. Estas generalizações não podem ser vistas como provenientes da incorporação da oralidade na escrita. A escrita é "corrida", sem diálogos, na cabeça dos pouco-letrados. A oralidade propicia o esclarecimento, por palavras, gestos, referências comuns, expressões fisionômicas. A oralidade do relato pessoal tende à quase extrema personalização - e ao testemunho. As generalizações decorrem de alguns fatores. Um é a idéia de que existe oposição radical entre oralidade e escrita: a generalização substitui a personalização, no hábito do escrevedor. Este hábito provavelmente está ligado à solicitação de textos dissertativos (solicitados como exercício preparatório para um vestibular longínquo e que, na verdade, poucos dos alunos submetidos a esta cobrança irão prestar). Como o aluno ainda não está preparado para a dissertação, generaliza. Por outro lado, atua a perda de noção de identidade própria e de confiança em si. Memmi indica como é estigmatizado

o colonizado. O que não aparece no texto de Memmi é que os papéis de colonizado e de colonizador pertencem a macro e micro grupos dentro de uma comunidade, sem que estes precisem corresponder exatamente aos membros de uma metrópole e de sua colônia. São repetidos por grupos dentro de grupos, a fim de garantir prestígio e hegemonia dos que detêm algum tipo, ou alguma ilusão de poder e de vantagens econômicas. Às vezes nem há vantagens econômicas, mas outras, como a condescendência para com pequenas irregularidades, que vão desde o atraso, ou as faltas, até a falta de compromisso mais radical com o trabalho.

Estigmatização "pega". O estigmatizado, se não tiver personalidade de batalhador, couraça de auto-suficiência, mais fortes que o estigma, cede a ele, inconscientemente, e passa a fazer de si a imagem negativa que corresponde ao

5. Esta adjetivação foi cunhada por aluna de Maria Nilde MASCELANI, criadora das Escolas Vocacionais, em episódio relatado por ela em conferência proferida para a APLL - Associação de Professores de Língua e Literatura.

${ }^{6}$. MEMMI, Albert. Retrato do colonizado precedido pelo retrato do colonizador. Trad. de Roland Corbisier e Mariza Pinto Coelho. Prefácio de Roland Corbisier. $2^{\mathrm{a}}$ ed. Rio de Janeiro: Paz e Terra, 1977. 
estigma. $^{7}$ Aí, generaliza, na escrita, aquilo que supõe serem os valores e discurso do grupo e cala o que é próprio e precioso. Poderíamos supor, também, que a generalização provém, direta ou indiretamente, da alienação provocada pelo discursos mitificantes da publicidade, da propaganda, de muitos dos livros didáticos disponíveis no mercado e da imagem de oprimido veiculada pelo discurso dominante ${ }^{8}$. O poder de penetração destes meios é o de representarem valores para a sociedade - portanto emuláveis e "comunicáveis". E como os discursos se especializam na sua destinação a públicos definidos, esta parcela da população escolar não apreende a diversidade temática e discursiva.

No texto acima, o detalhe foi descrito com palavras-clichês, como [...] ostentando sua beleza contra o azul profundo, ou ainda matizes que pincel nenhum conseguirá reproduzir fielmente. A imagem da paineira e do descampado poderiam ser observadas pelo autor mais atenta e longamente, ou com mais poesia. Algo, nesta redação, apresenta um alto nível de angústia, ou de insatisfação: é a contradição entre o desejo de ter um ritmo, que permita contemplação, e a impressão de que a cultura dominante exige produção e eficiência de serviços prestados, o que determina a pressa, a falta de concentração, a alienação de si e do mundo. Resulta do conflito entre a cultura dominante e a quase esquecida cultura de origem. Seria importante que o autor do texto desenvolvesse o tema de sua angústia ou incerteza. Apontado este aspecto rico, o autor do texto poderá sentir-se livre e não mais compelido a corresponder à força a um padrão negativo determinado e pré-fixado, às vezes existente, mais fortemente, na cabeça do próprio aluno.

Comparemos a idéia de consciência anestesiada diante do mundo da redação mencionada, com "A flor e a náusea" de Carlos Drummond de Andrade, a ser lida em nota de rodapé ${ }^{9}$.

\footnotetext{
${ }^{7}$ O filme Pride (2007), dir. Sunu Gonera, retrata um treinador de natação cujo lema para recuperar a autoestima de jovens afro-americanos marginalizados é Pride, Determination, Resilience (orgulho, determinação e resistência).

${ }^{8}$. Caso se note tal tendência na maioria das redações da classe, dois comportamentos são necessários. Um é tomar medidas para que a classe recupere a auto-estima; a capacidade de observação da realidade exterior ao indivíduo; a valorização de tal aptidão. A outra diz respeito ao trabalho com o texto do aluno.

${ }^{9}$ Uma flor nasceu na rua!

Passem de longe, bondes, ônibus,

rio de aço do tráfego.

Uma flor ainda desbotada

ilude a polícia, rompe o asfalto.

Façam completo silêncio, paralisem os negócios, garanto que uma flor nasceu.
}

Sua cor não se percebe.

Suas pétalas não se abrem.

Seu nome não está nos livros.

É feia. Mas é realmente uma flor.

Sento-me no chão da capital do país

às cinco horas da tarde 
O poema fala do tédio, da náusea, do nojo. Não menciona a anestesia diante da realidade. Ainda que seja usado o artigo indefinido (Uma flor nasceu na rua!), ele não é usado com exclusividade ao longo do poema. O poeta fala na rua, em bondes, ônibus, rio de aço, polícia, asfalto. As palavras do poema criam imagens fortes, claras, bem delineadas, sem indefinições. A percepção pessoal, particular, adquire, no poema, um outro valor, universal. Universalidade não é generalização: parte do particular para assumir um caráter que transcende o pessoal, sem deixar de ter raízes ancoradas no detalhe, no próprio e especial.

Ao generalizar, o texto relativiza ou anula o valor do real, concreto, através da remessa das palavras que se referem a personagens, espaço, tempo, para o vago, para o indefinido. Frequentemente, quando o autor de uma redação escolar introduz uma personagem em seu texto, ela, quando muito, é identificada pelo seu papel dentro do grupo social (como sucede com boa parte da literatura infantil, segundo estudo de Fúlvia Rosenberg ${ }^{10}$ ). São homens, seres humanos, pais, mães, filhos, ladrão, criança, empregada, um rapaz (uma moça). As personagens não são caracterizadas. São entidades genéricas, como "o viajante", "todos nós", "se" (de "não se sabe"); a primeira pessoa do plural ("nós"); a primeira pessoa do singular ("eu"). Estas últimas formas genéricas de personagem são as mais freqüentes.

Nos textos estudados as personagens são, por excelência. Suas características são vistas como perpétuas. Daí a naturalização e a intransitividade, a falta de ação, a suspensão do tempo. Podem ser contraditórias, passando de uma característica a outra, sem transição, sem processo. A memória do autor-narrador perde sua vivacidade, despoja-se do que tem de pessoal para transformar-se em elemento generalizador e indefinidor.

Algumas informações facilitam a compreensão de um relato. Em uma adivinhaanedota pergunta-se a respeito das características da personagem da adivinha. "Trata-se de um homem que mora no $27^{\circ}$ andar. É perfeito, tem braços, pernas e mãos, direitinho. Todos os dias desce de elevador para sair de casa em direção ao trabalho, mas não consegue subir de elevador além do $15^{\circ}$ andar, subindo o resto dos andares sempre pela escada. Por que, ao voltar, sobe todos os dias até o $15^{\circ}$ andar e sobe os andares faltantes a pé?" O interlocutor poderá imaginar que se trata de um exercício especial feito por nosso homem todos os dias. A informação esclarecedora e faltante, chave para resolver o enigma, é que ele é muito baixinho e só consegue levar a mão até o botão do $15^{\circ}$ andar. Só chegamos a adivinhar o enigma-piada graças ao conjunto das outras informações, em que fulano é todo ele caracterizado fisicamente.

e lentamente passo a mão nessa forma insegura.

Do lado das montanhas, nuvens maciças

avolumam-se.

Pequenos pontos brancos movem-se no mar, galinhas em pânico.

É feia. Mas é uma flor. Furou o asfalto, o tédio, o nojo e o ódio.(.) DRUMMOND DE ANDRADE, Carlos. "A mão suja". In:_. Antologia poética. 13 ed. Rio de Janeiro: José Olympio, 1979. p. 12.

10. ROSENBERG, Fúlvia. Literatura infantil e ideologia. São Paulo: Global, 1984 (Teses, 11). 
Informações sobre porte, estatura, expressão fisionômica, cabelos, olhos, nariz, mãos, pés, corpo da personagem, ou informações sobre o vestuário ou tiques nervosos, sobre a família ou a idade, podem permitir a melhor compreensão do que se conta, se o que se conta depende de uma caracterização deste tipo. Como a personagem vive no tempo e espaço, interessa conhecer o que seja relevante do passado, presente, projeção para o futuro, e o ponto com respeito a esta linha cronológica em que se situa a personagem. A contextualização da personagem - ou do que se diz - é condição sine qua non para a compreensão.

Talvez o autor de uma redação tenha a ilusão de que usando a primeira pessoa do singular e o pronome pessoal de primeira pessoa seria suficiente para personalizar o texto, dando-lhe até foros poéticos de beleza e profundidade. Mas o uso do "eu" apenas informa acerca de um ponto de vista de onde emana a narrativa: o narrador se identifica como narrador que viveu o acontecido na categoria de personagem, não contextualizando a informação, nem caracterizando tempo, espaço, personagens. Para que exista comunicação - e compreensão - é indispensável contextualização verbal. A ilusão da imediatez da cadeia comunicativa leva um autor (aluno) a acreditar que sua identidade própria, independente da palavra escrita, passa para o papel na medida em que assume o discurso em $1^{\text {a }}$ pessoa e assina o seu nome. E pressupõe que $o$ conhecimento entre os interlocutores baste para caracterizar contextos. Do outro lado da cadeia comunicativa, imagina um único receptor: o/a professor/a que ele conhece pelo nome, de vista, de atitudes e critérios de avaliação. Muito do que na comunicação oral é mediado pela vizinhança dos corpos, por gestos, meneios, trejeitos, entonações, olhares e piscar de olhos, dicções, entonações são referências a constarem do texto escrito. $\mathrm{Na}$ comunicação oral o silêncio, a ruptura da enunciação, a falta de contexto, poderão ser esclarecidos através de pergunta e resposta. Na escrita, o leitor automaticamente se converte em um outro, sem subsumir a identidade do emissor. Quando inserido como personagem ou voz narrativa dentro do texto, transforma-se em uma entidade abstrata cristalizado na palavra. O leitor precisa receber todas as informações necessárias dentro da mensagem, i.e, dentro da redação - para entender de que, o que - e para que se fala $^{11}$. Afinal, contextualizar é fornecer, dentro do texto que se escreve, todos os dados necessários para que ele seja entendido pelo leitor, qualquer que ele seja.

A produção de textos escolares não tem levado em conta o leitor. No lugar dela, fora da cadeia comunicativa, o leitor, identificado com o professor, assume o papel de juiz absoluto, onisciente, onipotente, onipresente, que só quer medir o conhecimento

11. Há quem pense que o uso da primeira pessoa - eu-autor - seja típico de crianças de menos de 10, 11 anos. Será? Crianças pequenas inventam histórias. Suas personagens podem ser animais, objetos, seres humanos, relatados em uma história que tem a forma dos contos de fadas, contendo, mesmo, aspectos do inconsciente, ou do inconsciente coletivo. $\mathrm{O}$ contacto com a escola traz à criança um choque cultural - cultura dominante versus cultura de origem. E a cultura dominante é apresentada como sendo o domínio da escrita, enquanto que o domínio da oralidade pertence à cultura de origem. $\mathrm{O}$ que acontece é que não há uma introdução, para a criança, sobre as diferenças entre a oralidade e a escrita. Uma das diferenças fundamentais é que a escrita constitui um registro, uma representação do mundo. O mundo representado, é óbvio, natural, automático nas relações orais. A criança (e o jovem - e o adulto) que usa a primeira pessoa idêntica ao autor, faz da primeira pessoa um uso ingênuo, decorrente de informação sobre as características diferentes entre oralidade e escrita. 
dos alunos - ou a sua criatividade - e coesão. Se o que se avalia é a criatividade, precisamos defini-la primeiro. E o que mais é a criatividade que a capacidade de contar o que quer o autor, do seu jeito, a partir de sua experiência pessoal, seja concreta e real, seja da fantasia, ou de sonhos, leituras, ou hibridismos diversos. E o que vale a experiência pessoal sem confiança na capacidade pessoal de ver, ouvir, sentir, perceber, pensar, ler, lembrar e comunicar oralmente ou por escrito através da palavra? E o desejo de fazer-se entender, da melhor e mais completa forma possível? Isto não impede que, se o que se quer transmitir é o absurdo do mundo, se possa trabalhar o texto com elementos do absurdo. A funcionalidade e necessidade determinam a palavra e o estilo.

O texto afetado por auto-imagem comprometida, por insegurança, apresenta marcas de linguagem a ser lembradas:

- o detalhe observado é transformado em verdade geral, comum a todos os seres humanos;

- os pronomes indefinidos substituem a caracterização de personagens ("Ninguém observou. Ninguém observa. Todos perdemos a capacidade de ver [...]");

- uso excessivo de pronomes adjetivos indefinidores (aquele, aquela, certo, certa, ninguém, algum, alguém);

- uso quase exclusivo de artigos indefinidos;

- uso de adjetivos apenas intensificadores, vazios de sentido (grande, grandioso, muito, imenso, enorme);

- uso de termos que restringem as afirmações no texto (modalizadores), do tipo: pode ser, sem dúvida, parece-me, parece, deve ser, acho, mais ou menos, talvez, sem função estética ${ }^{12}$.

Identificadas estas marcas, o trabalho a ser feito é mais de afirmação da cultura própria, de ampliação de referências culturais, sempre afirmando a de origem, do que o de crítica. A afirmação, a positividade levarão à expressão mais adequada, plena e rica.

12. Comparemos dois textos: "O homem que me atacou tinha $1,70 \mathrm{~m}$, era magro, tinha cabelos e barba loiros, olhos verdes, mãos grandes, vestia calça jeans e camiseta branca, mas calçava sapatos pretos de verniz, sem meias." E: "Acho que a pessoa que me atacou era um homem. Não era nem muito alto, nem muito baixo. Parece que era magro, mas não tenho certeza. Os cabelos... Será que eram castanhos, ou loiros? Também podiam ser pretos. Não sei: estava muito escuro. Não reparei na roupa que usava." Que imagem fica? A primeira descrição permite a visualização da pessoa ou personagem. Da segunda descrição fica uma imagem incerta, borrada, como se houvesse uma cortina, ou uma nuvem na frente. De onde provém este efeito? Do uso das palavras indicadas, que se chamam "modalizadoras". Este recurso pode ser útil se se quiser tornar incerta a percepção de apenas um trecho, momento ou circunstância da narrativa. Como recurso exclusivo, que aparece na narrativa inteirinha, o leitor não conseguirá fazer uma idéia de que é que o narrador e o autor pretendem contar. 
Do discurso com linguagem generalizante decorrem:

\section{Vagueza}

A modalização costuma ser usada em redações como sintoma de insegurança no uso da palavra, decorrendo do desejo de relativizar aquilo que o emissor afirma. Outro uso que constrói a vagueza é o de palavras que criam uma expectativa de precisão, seguidas de descrições imprecisas, como em:

Como provas de desenvolvimento numero as tantas rodovias, rasgando nossas terras; a crescente técnica, a construção de navios e a aeronáutica já construindo seus primeiros pássaros voadores com muito sucesso.

Faltam informações para que se entenda o que o autor quer dizer. As provas não provam nada. A numeração é seguida pelo pronome adjetivo indefinido: "as tantas rodovias", sem cumprir com a anunciada enumeração, ou nomear as rodovias mencionadas. É uma linguagem que tende a frustrar as expectativas, a dar menos que o prometido, mas sem aproveitar o recurso da frustração de expectativas com alguma finalidade estética ou semântica.

Quando leio Isto tudo é porque só agora vejo que o trajeto que percorremos, aguardo, como leitora, uma descoberta nova, excepcional, acerca do que vê o emissor. Ao invés desta revelação esperada, lê-se algo banal - lugar comum, máscara exatamente o contrário do que anuncia o verbo "ver". O visto não é informado, mas aquilo que se convencionou dizer que ocorre. É uma linguagem que não se compromete. Que quer dizer Devemos aproveitar ao máximo o trajeto da vida? É "vencer na vida"? É passar a vida monasticamente, para conquistar o reino dos céus? É perder os limites?

${ }^{13}$. O conceito de "frustração de expectativa" foi trabalhado por Roman Jakobson. Tendo em vista que a organização das palavras em um texto de poesia ou prosa desperta uma expectativa por parte do leitor, Jakobson mostra que uma das formas de trabalhar com este recurso será, em vez de despertá-lo, frustrá-lo. Para maior clareza exemplifico com um início de poema de Carlos Drummond de Andrade. O poema chama-se "A mão suja". O primeiro verso é "minha mão está suja". Tanto o título como o primeiro verso despertam, em mim, leitora, a expectativa referente à idéia de "mão suja". Espero ou bem que ele explique a sujeira, ou bem que a elimine, lavando a mão. Mas o poema segue:

A mão suja

Minha mão está suja

Preciso cortá-la

Não adianta lavar

A água está podre.

O poema segue, mas eu, leitora, levei um choque quando li o terceiro verso "Preciso cortá-la". A este tipo de choque, ou decepção, se dá o nome de frustração de expectativa. 
A não especificação não corresponde a uma visão democrática. Corresponde quer à ausência de visão, quer ao compromisso com o discurso dominante a fím de evitar conflitos com seu interlocutor ou leitor, custe o que custar. Decorre também a perda da poesia.

\title{
3. Dogmatismo.
}

Apesar de os textos examinados conterem imprecisões, indefinições, indeterminações, tendem ao dogmatismo, que compensa a insegurança real com uma segurança aparente. Pessoas inseguras tendem a gritar, dar ordens, mais facilmente que pessoas seguras. São frágeis e, nesta fragilidade, suscetíveis, chegando a ser agressivas. $\mathrm{Na}$ linguagem isto se revela através de afirmações categóricas, assertivas: Subdesenvolvimento é uma nação onde não há ideal, onde impera a anarquia. Aqui no Brasil estamos coordenando tudo, tudo.

As asserções - categóricas - dos textos escolares talvez reproduzam o dogmatismo da escola e das diferentes instâncias do poder. Substituem a clareza de idéias próprias.

O dogmatismo é confortável para a ética e moral de uma sociedade, porque incentiva os complexos de culpa, que exercem a atração do pântano.

\section{Maniqueísmo.}

\author{
acepções: \\ Segundo o Novo Dicionário da Língua Portuguesa, a palavra tem duas
}

- Doutrina do persa Mani ou Manes (séc. II) sobre o qual se criou uma seita religiosa que teve adeptos na Índia, China, África, Itália e Sul da Espanha, e segundo a qual o Universo foi criado e é dominado por dois princípios antagônicos irredutíveis: Deus ou o bem absoluto, e o mal absoluto ou o Diabo.

- Doutrina que se funda em princípios opostos, bem e mal.

\footnotetext{
14. A redação foi escrita no ano de 1971, ainda em plena ditadura e campanha ideologizadora militar, que pretendia inculcar na população a idéia do milagre econômico.

15. FERREIRA, Aurélio Buarque de Holanda. Novo Dicionário da Língua Portuguesa. $2^{\mathrm{a}}$ ed. revista e aumentada ( $4^{\mathrm{a}}$ impressão). Rio de Janeiro: Nova Fronteira, p. 1081.
} 
Ainda que os textos escolares não participem de uma doutrina religiosa, ou espiritual, tendem a ser maniqueístas, como as novelas de TV, os seriados americanos, quer sejam a saga de uma família, quer se trate de aventuras, ou filme policial.

Os textos triviais, ou trivializados (novelas, fotonovelas, séries televisivas) têm a intenção de convencer o espectador de que aquela é a verdade e corresponde ao retrato do Brasil. O texto produzido por alunos não tem esta pretensão. Provavelmente por isto seu maniqueísmo é desigual, indiciando quer a precariedade de forças pessoais e do grupo, quer solidão, sentimento de culpa etc. São dois lados de um problema: o produtor do maniqueísmo incute idéias, concepções do mundo, ideologias. O produtor de redações, que apenas absorve o maniqueísmo, não apresenta um texto coerente. $O$ questionamento ou nova visão intuídos pelo emissor são silenciados. Os erros constroem interstícios - rastros - da visão de mundo recalcada.

Os modelos para estes clichês estão sobretudo na literatura trivial e trivializada encontrável em livros didáticos, na literatura infanto-juvenil, no material escrito destinado ao público médio, visto como de Q.I. baixo, de desenvolvimento mínimo e entendimento limitado. A estratificação das relações compõe o quadro que resulta (não obrigatória, mas bastante provavelmente) na estratégia de justaposição de frases e partes do relato ligadas por $e$, aí, e daí, então, foi então. Os clichês e as repetições esvaziadas constituem muletas: representam o desejo de comunicação. $\mathrm{O}$ recurso às fórmulas conhecidas pelos dois lados da cadeia comunicativa parece garantir a superação do fosso que separa o aluno do examinador, do professor em sala de aula, do superior. $\mathrm{O}$ fenômeno não é novo. Pareceria que tanto a inadequação de padrões entre escola e comunidade, como as estratégias de intimidação, têm se repetido ao longo do tempo.

A leitura de textos ficcionais em que não ocorre o uso de clichê, ou em que o clichê é renovado, parodiado, invertido, ironizado, que substituiria o repertório de clichês absorvidos, depende de o estudante ter adquirido o gosto pela leitura. Este é desestimulado pela insegurança, pela baixa auto-estima. A observação da realidade externa, do mundo que cerca o indivíduo, e a construção de autoconfiança poderão ser trabalhados através da conversa em sala de aula, da pesquisa de aspectos do mundo que rodeia o aluno e da produção de textos a partir de pesquisa, cotejando a realidade e sua representação e examinando as diferentes formas de representação. São estratégias pedagógicas que poderão ajudar a compor uma imagem do mundo e de si no mundo mais equilibrada, menos onipotente e despida de clichês - assim como despida de sentimento de inferioridade, odioso produto dos estigmas.

\section{Redundância ${ }^{16}$}

16 Trajeto

Trajeto traz implicações de ponto de partida e de chegada. Sai-se de um ponto que foi fim de outro trajeto para se chegar a um fim determinado que, conseqüentemente, também não é o ponto final.

Sabe-se somente de um marco momentâneo de partida e no trajeto, as coisas acontecem, são os inúmeros instantes - já no cotidiano de cada um. 
Não é incomum encontrar-se redundâncias (ou repetições, ou tautologias) nas redações de alunos. O texto gira em torno da mesma noção sem conseguir desenvolvêla.

A recorrência da redundância decorre também de insegurança e ilusão de que o professor quer e espera um texto de cunho filosófico. Tratarei abaixo do discurso filosofante. Quero salientar, contudo, que a redação transcrita na nota 16 acena para uma idéia rica: é a noção do tempo feita pela somatória dos instantes no presente, contraposta a uma medição de instantes, ou de circunstâncias, feita a partir do conceito de começo e fim, ou de causa e conseqüência. Desenvolver estas idéias do ponto de vista filosófico é difícil. Seria preciso estudar antes alguns filósofos e suas teorias. Mas é possível apanhar estas idéias, relacionadas como estão, e desenvolvê-las em uma história, ou em um "caso".

Eglê Pontes Franchi vê o recurso à repetição como um modo de estabelecer as ligações entre as frases e as partes de uma redação (isto é, como pontuação e recurso fático). Ela analisa o uso das anáforas a partir da seguinte redação:

Era uma vez eu tinha um pintinho ele era muito bonito ele era acostumado comigo a onde eu ia ele ia atrás ele era meu.

Um dia minha tia estava na minha casa e estava aquela correria e o meu irmão pisou nele e ele morreu eu fiquei muito triste.

Diz ela:

[...] trata-se de elementos anafóricos, isto é, que relacionam expressões do enunciado com elementos anteriores no discurso; desse modo as orações se ligam pela relação anafórica que se estabelece entre elementos comuns: em outros termos, as duas orações "falam" de um certo modo dos mesmos elementos. Outras expressões que são usadas com o mesmo valor são "assim", "aí", etc.

Por que aparecem nas redações as repetições (ou a tautologia, ou o uso de anáforas)?

A fuga pela tautologia, ou pela repetição idêntica, só com outras palavras, ou da repetição das mesmas palavras, desnecessariamente, decorre, também, do temor de sua explicação não ser acolhida. Os objetos, as pessoas, as circunstâncias, privadas de História, não têm explicação possível. E a cultura dominante tende - ainda - a silenciar histórias, realidades, levando o ser atingido por isto a se sentir desestabilizado em seu mundo, diante do mundo dos outros.

A dupla morte, da racionalidade e da linguagem, ocorre já nos primeiros passos escolares. O que se considera irracional, na criança, é uma forma de desvendamento do mundo, que, verbalizado em outros termos, seria racionalizável, ou francamente poético. Isto é difícil e visto como perigoso por adultos (professores, mas não só os de

O trajeto soma uma série de trajetos - já.

${ }^{17}$. FRANCHI, Eglê Pontes. E as crianças eram "difíceis". A redação na escola. São

Paulo: Martins Fontes, 1984. 
$1^{\circ}$ e $2^{\circ}$ graus). Trabalhar com poesia é difícil, ou assustador. Evita-se, pois, maiores riscos. Dificilmente são aceitos os neologismos infantis pelos olhos e ouvidos dos adultos em situação de docência de nível primário (sempre há exceções): o dicionário precisa ser seguido, já que "é preciso ampliar o vocabulário - ou léxico - do estudante". O autoritarismo do interlocutor, a desvalorização crítica e cruel do outro, levam o sujeito submetido à autoridade desvalorizadora a conter o pensamento, por medo da linguagem - dos adultos.

Esta é a explicação. Outros querem que não. Acham que uma criança, por falta de vocabulário, estruturas verbais e repertório, só pode escrever assim.

O valor do trabalho de Eglê residiu em mostrar o equívoco de tais hipóteses. A partir da valorização do repertório de origem da criança e da sua ampliação através da leitura de alguns textos, Eglê conseguiu, em um semestre, de crianças consideradas problemas, já várias vezes repetentes, um desabrochar assombroso. De repente conseguiram escrever fluentemente, com um vocabulário hipoteticamente inexistente em criança desta idade e formação ${ }^{18}$.

18. Santa Calcedoni VERGARI, professora alfabetizadora, em Piracicaba atualmente, tem um belíssimo trabalho, em que reúne ficção e realidade, e em que a convivência com algumas personagens criadas a partir de nomes próprios que lhe pareceram conter sons e letras com certas dificuldades para a alfabetização, permite familiaridade, perda de medo do novo e desembaraço no uso da palavra já no processo de alfabetização. $O$ resultado do trabalho são textos em que construção, uso de recursos de linguagem, ortografia, uso da norma culta, aparecem com naturalidade e fluência. (Tenho, por cordialidade de Santa C. Vergari, um caderno de aluna sua, caderno de férias - portanto correspondente ao fim da $1^{\mathrm{a}}$ série, antes do início da $2^{\mathrm{a}}$ - do qual escolho uma redação, a fim de comparar com a redação produzida em início de $3^{\mathrm{a}}$ série, por um dos alunos "problema" de Eglê Franchi, transcrito acima.

(Desenho)

Dia 17 de janeiro de 1989.

A menina e o ratinho falante!

Um dia uma menina que se chamava Cláudia estava andando pela floresta e de repente ela encontra um ratinho.

A menina disse:

- Nossa que ratinho bonitinho!

O ratinho falou:

- Quem eu?

Ei ratinho você fala também falou a menina.

Cláudia estava meia confusa mas entendeu que o ratinho era falante.

Cláudia disse:

- Nós dois podemos ganhar muito dinheiro com você!...

O ratinho falou:

- Mas o que é dinheiro?

Cláudia disse:

- Eu te conto no caminho!

Quando Cláudia chegou em sua casa ela deu um bom banho no ratinho, e também colocou roupinhas nele.

Cláudia procurou um circo para colocar o ratinho. 


\section{Discurso filosofante}

Desde o começo da escolarização, a linguagem tanto oral, como escrita, veiculada para o aluno pelos livros didáticos é pedagógica e didática. Pretende ter sempre, ou quase sempre, um ensinamento. E o que se espera do aluno, é que reproduza esta linguagem. O que é apresentado como sendo o padrão culto é, muitas vezes, o preconceito que se tem do que este seja; isto é, seria antes o padrão culto restrito a um tipo de texto: o texto dissertativo. Segundo esta perspectiva, o padrão culto seria também objetivo, racional, lógico. Para isto é preciso ter argumentos, a favor ou contra, a respeito do assunto tratado, argumentos que não correspondem ao estágio escolar deste aluno. Isto leva o aluno a acostuma-se a realizar tarefas para as quais não está maduro. Não dispondo, ainda, de conhecimentos necessários e suficientes para dissertar, o aluno acostuma-se a se "virar". Usa as estratégias de preenchimento, na verdade e em português escolar, equivalentes ao que no meu português chão se chama de "enchimento de lingüiça". Este é acrescido, ou composto pelo "discurso filosofante", sobretudo e mais facilmente se o tema for fácil e perigosamente próximo ao clichê e este contiver uma asserção que sequer permite o levantamento de argumentos científicos, como um tema que já apareceu em vestibular. "Todo homem é uma ilha". Bela frase. Tenhamos em conta que quem a cunhou foi John Donne, poeta inglês do século XVI, em "Meditações XVII", de seu livro Meditações, que contém reflexões do autor em relação à perenidade da vida e à preparação do corpo e do espírito para o encontro final com $\mathrm{o}$ criador. A retirada da frase do contexto ${ }^{19}$, a ignorância a obra de John Donne, esvazia a colocação e permite ser preenchida com o que quer que seja. Quem formulou o tema da redação conhecia o contexto - repertório oculto - e foi considerado genial. Quem se confrontou com o tema só poderia "chutar". E considerar-se ínfimo. Neste sentido é uma traição para com o próprio indivíduo ${ }^{20}$.

O nome do ratinho era assim "O grande rato falante".

O rato não gostou muito do circo e resolveu fugir.

$\mathrm{O}$ ratinho falante fugiu e a menina não o encontrou mais.

Regina Cláudia Oliveira Moura.

A teorização de seu procedimento ainda não foi feita por ela - está a caminho, ainda que com dificuldades - mas pareceria que as dificuldades na produção de textos são antes uma dificuldade em ensinar, do que dificuldades propriamente do aprendiz.

19 "Talvez aquele por quem os sinos dobram esteja demasiado doente para saber que dobram por ele; e talvez eu possa achar que me encontro bem melhor do que estou, do que aqueles que me rodeiam podem perceber e notar o meu estado, de maneira a pedir que os sinos dobrem por mim - e eu não o saiba. [....] Nenhum homem é uma ilha, sozinho em si mesmo; cada homem é parte do continente, parte do todo; se um seixo for levado pelo mar, a Europa fica menor, como se fosse um promontório, assim como se fosse uma parte de seus amigos ou mesmo sua; a morte de qualquer homem me diminui, porque eu sou parte da humanidade; e por isso, nunca procure saber por quem os sinos dobram, eles dobram por você.

${ }^{20}$ Eis uma redação com "discurso filosofante".

$\mathrm{O}$ viajante

Todos nós somos eternos viajantes, andar, caminhar sempre, conhecer novos lugares, outras pessoas, pois é pela incessante caminhada por diversas veredas que conhecemos uns aos outros, e adquirimos vivência, imprescindível para que amplie nosso cabedal de conhecimento. Desde o início da história da vida dos habitantes da terra das tribos dos grupos humanos que se locomoviam de lado para lado e se afirmando aqui ali que foi possível a evolução e a lingüística, e outras áreas da ciência se fundamentou baseados 
Além de produzir o discurso filosofante e outras mazelas, a insistência na produção de dissertações não ajuda nem sequer a preparar o aluno para a dissertação que fará, eventualmente, caso resolva fazer uma pós-graduação, o Mestrado e o Doutorado. Para se adaptar à dissertação, solicitada bem mais adiante para o ingresso à universidade, e por considerarem que a universidade que avalia é reduto da intelectualidade (entenda-se toda a fantasia que envolve a imagem, por parte dos que estão do lado de fora), a escola pede precocemente dissertações de seus alunos. Ora, o aluno não está maduro e não armazenou conteúdos que lhe facultem dissertar. Como isto lhe é pedido numa fase em que o aluno não está preparado para a tarefa, o aluno entende que lhe é solicitada a visão global de mundo (que ele não tem; por isto generaliza) e a capacidade de reflexão teórica (confundida com o filosofar).

A legítima filosofia necessita de estudo, reflexão e maturidade. Sobra ao aluno de $1^{\circ}$ ou mesmo de $2^{\circ}$ graus (salvo raríssimas exceções) um "filosofar" de cozinha, (pequeno-burguês?). Não se prende mais à sabedoria popular, elemento negado na cultura urbana, porque recoberta pela cultura do dominador. Para garantir a desqualificação desta cultura, age a publicidade, a produção cultural para as massas, textos de livros didáticos, preconceitos, que incluem a imagem negativa da gente simples, dos "carentes", das classes menos favorecidas. Num só bloco, o preconceito reúne pobreza, feiúra, deselegância, baixa inteligência, baixo nível de informação. Conselheiros, ministros, reis, príncipes são sempre inteligentíssimos. Ainda que possa haver quem diga que os contos de fadas contribuem para esta imagem, contraponho rapidamente "A roupa nova do rei", em que todos, menos um meninozinho, têm limites. Como o mito da inteligência ligada a governantes era muito forte, dificilmente ocorreria, em uma redação das décadas da ditadura militar ou próximas a ela que o chefe de Estado de país amigo não soubesse o nome do país que está visitando. E em

nos viajantes e até hoje todos querem melhorar economicamente, socialmente, para que? Viajar, conhecer novas terras, ao lado da higiene mental, somar também seus conhecimentos pesquisas. Só podem argumentar com precisão e segurança o indivíduo que dispõe de grande cabedal intelectual e que este é dado pelas leituras, viajando, se comunicando, podendo assim se entrosar com elementos vários nos diversos campos da ciência.

O viajante foi e será sempre aquele que desvenda a cortina do passado, do presente e do futuro. Viajante eterno enamorado da natureza.

Sabe amar a noite cheia de estrelas.

$\mathrm{O}$ dia ensolarado. O mar, o céu e a terra.

Ser viajante é ser mensageiro de Deus, é ele que leva e trás novas mensagens fazendo o intercâmbio entre pessoas, unindo assim, Deus, a Pátria e a família.

Viajar sempre, em vida e depois da morte, depois dessa melhor ainda, pois conheceremos novos mundos, passearemos pelas galáxias, e iluminados pelos fluídos benéficos do Senhor tornaremos límpidos translúcidos e habitaremos novos planetas. Seremos então os eternos viajantes.

Viajante é o homem feliz que sabe amar a vida, sentir o perfume das flores, apreciar o gorjeio dos pássaros, penetrar por caminhos sem fim, aqui e ali o aconchego de uma mão amiga. É viver, quem não viaja não vive.

Viajar é viver.

Viver é amar.

Amar é sonhar.

Sonhar é se construir 
1982 Reagan, presidente dos EUA, ao chegar ao Brasil manifestou sua alegria em chegar à Bolívia...

A maior dificuldade do discurso filosofante é a falta de desenvolvimento dos diferentes tópicos abordados. Misturados e indiferenciados, eles se interpenetram, perdendo o seu sentido. Separados, há temas relevantes:

Só pode argumentar com precisão e segurança o indivíduo que dispõe de grande cabedal intelectual. (O tema abordado seria o do repertório necessário para uma dissertação ou outro texto argumentativo.)

[...] podendo assim se entrosar com elementos vários nos diversos campos da ciência.

O autor percebe a importância do reconhecimento e aceitação das diferenças. Esta percepção é perturbada pela força impregnadora da concepção de "cultura dominante" como equivalente à cultura propriamente dita. A idéia de "viagem", "pesquisa", "cabedal intelectual" converge para o que se entende como cultura padrão.

Os preconceitos tolhem o autor do texto. Hesita entre dizer sim e não à idéia de viagem. É que não sabe o que espera o professor e teme se comprometer. De tanto medo, se compromete com a expressão inadequada, vaga, generalizada, filosofante. Tece apenas considerações, sem contar uma história. Os comentários são fragmentados por falta de eixo central.

\section{Personificação do inanimado ${ }^{21}$}

${ }^{21}$ Eis um exemplo do uso da personificação do inanimado.

Um dia uma árvore muito feliz e verdinha, sorrindo para o mundo, parou, olhou ao seu redor e sentiu medo.

Ficou apavorada e pensou logo consigo mesma:

- Será que eu vou viver eternamente? Talvez eu esteja enganada, mas tenho um estranho pressentimento de que algo horrível vai acontecer comigo. Por que isso? A minha vida tem sido tão boa: Eu vivo num imenso paraíso, rodeada das minhas belas e majestosas companheiras de quem eu gosto tanto.

Estou sentindo frio, muito frio, parece uma chuva de neve caindo sobre mim. Essa neve está penetrando no meu frágil corpinho de árvore. Meus galhinhos estão endurecendo, estou molhadinha!

Não, não posso deixar que isso aconteça, preciso fazer alguma coisa para mudar o meu triste destino... Mas, o que uma humilde e solitária arvorezinha poderá fazer? Eu não queria morrer agora e deixar o meu jovem pinheirinho que eu adoro (sem ele saber, por causa dessa boba timidez que sinto):

Engraçado, o frio passou, tudo sumiu... Agora estou achando tão quente, como se estivesse distante, pertinho do sol, vivendo junto com as estrelas, longe deste mundo cheio de tristezas e decepções. 
É bastante freqüente a personificação do inanimado, ou antropomorfização. Consiste em dar vida humana a uma planta, a um objeto ou animal.

Tem sido usado com freqüência, no lugar de uma descrição identificadora, atribuir fala humana a minerais, vegetais ou animais. As personagens seres humanos, quando aparecem nestas redações, são indeterminadas ("um homem", "um menino") e não são caracterizadas. O recurso em si é antigo, quando, para além de falar, a planta, o mineral ou o objeto, coerentemente tem uma determinada função que corresponde àquela planta, pedra, ou objeto. No conto "Um apólogo", de Machado de Assis, falam entre si a agulha e a linha. Quais são as diferenças possíveis entre esse recurso aceito e este outro que aponto como marca das pressões sociais?

Nas fábulas, os animais falam, têm mobilidade e as suas características correspondem aos traços simplificados das personagens humanas. Neste sentido, o animal não é uma entidade abstrata, nem as características são fortuitas. Além disto, os animais representam uma comunidade que fala e não só um animal, planta, mineral ou objeto isolados. $\mathrm{O}$ falante pertence a um mundo em que os animais (ou etc.) falam. É um universo em si, com características próprias. Nas fábulas, há pares que falam entre si. O diálogo das fábulas, no mais das vezes, é usado para caracterizar uma situação de desigualdade social e os animais, ou a agulha e a linha, são usados como metáforas de uma situação humana, mais facilmente retratável através deste recurso. Ele provoca o estranhamento, que leva à visão crítica da situação delineada.

Nos textos escolares em que aparece o recurso da personificação do inanimado, o seu autor atribui vida humana a uma árvore, a uma gota d'água, a uma pedra. Comumente são atribuídas reflexões a entidades (plantas ou pedras) não relacionadas à natureza própria de tal planta ou pedra. Quais as características de uma árvore? Ela tem variáveis tempos de crescimento, decorrentes da fertilidade ou penúria do solo, das características do clima, de acontecimentos naturais, como fogo, ciclone, tufão, inundação. As árvores têm uma única direção de movimento: para o alto. E são afetadas pelo vento, movendo apenas seus ramos e folhas. Podem abrigar aves e conviver com outro tipo de vegetação própria de seu hábitat. Têm raízes que se alastram. O desejo de luta de uma árvore, ou de movimento não corresponde às suas características. A personificação do inanimado mal empregada acaba gerando um fundamental fenômeno de inverossimilhança. É um recurso que não funciona, a menos que seja acoplado ao diálogo com outra planta ou mineral antropomorfizado. As fábulas sempre usam o diálogo.

Ah, parece que tem gente querendo me derrubar, sinto muitas picadinhas, estão cortando o meu lindo caule!

Ah, que fumaça! Esse mal que ataca e destrói a Natureza Viva, matando-a, estragando as árvores, fazendo com que seus frutos cresçam pequenos e sem sabor, tirando as vitaminas que eles contêm. Os pássaros, voando pelo azul do céu, se sentem fracos, sem forças para continuar a sua jornada sem fim através das montanhas e dos mares. Vou lutar! Nem por um momento sequer irei fraquejar diante da minha missão! Lutarei! Acho que vou vencer, acabar com tudo que não presta e habitar o meu reino! A Natureza será então muito saudável. 
Como a antropomorfização depende também deste mundo sócio-político dentro do qual vivem os seres personificados, é de difícil uso. Não é de espantar que o uso equivocado, incompleto, não abra espaço para a crítica à sociedade, embutida no recurso à antropomorfização. Perde-se, por falta de vida na personagem, por ausência de grupo social ao qual pertence a personagem, o valor simbólico do procedimento. Quando uso a perífrase personificação do inanimado penso no uso inadequado, equivocado do procedimento. Antropomorfização será usado por mim, daqui para a frente, para o uso do recurso de forma plena.

A redação transcrita em nota ganhou o primeiro lugar num concurso interno, em escola de $1^{\circ}$ grau ( $7^{\mathrm{a}}$ série). Sua grande força reside na expressão de entusiasmo, de impulsos de vida apaixonados, no desejo de luta. Ela também está bem escrita (sem erros de ortografia e sintaxe) e tem um desenvolvimento harmonioso. Não apresenta os defeitos mais gritantes do uso inadequado da personificação do inanimado (por isto mesmo não chamou a atenção como uma redação insuficiente). Entretanto, os lugares comuns (árvore muito feliz e verdinha; estranho pressentimento; imenso paraíso; belas e majestosas companheiras; triste destino; humilde e solitária arvorezinha; jovem pinheirinho; boba timidez; frágil corpinho; lindo caule; esse mal que ataca e destrói a Natureza Viva; fazendo com que seus frutos cresçam pequenos e sem sabor, tirando as vitaminas que eles contêm; jornada sem fim através das montanhas e dos mares; nem por um momento sequer irei fraquejar diante da minha missão; natureza saudável), o uso do monólogo e as três frases finais comprometem o texto. A árvore que está sendo derrubada não poderá lutar contra seus agressores; menos ainda em termos abstratos, em nome da Natureza e não em nome de sua existência e das árvores que a rodeiam. A árvore da narrativa é genérica: não apresenta características a não ser as da espécie vegetal, de modo que a ação nada tem a ver com a personagem. Um pinheiro esguio poderá ser altivo, vaidoso, sendo verossímil que discuta com um arbusto mirrado sobre a beleza de seu porte. Uma seringueira poderá ser um tanto selvagem - e protetora. A ação da narrativa teria que ser construída em função desta característica. Os sentimentos humanos não foram retratados nesta personificação, de modo que ela funciona apenas como substituto de uma descrição. Descrição difícil, sofrida, porque o autor não refletiu sobre o que é e como é a árvore; não se decidiu sobre o tamanho e resistência da personagem - árvore. Há noções confusas sobre ecologia, biologia vegetal, sentimentos (psicologia), que se anulam na insegurança do conhecimento. Não será mais fácil escrever sobre o que se domina melhor?

\section{Linguagem intransitiva e transitiva.}

Roland Barthes, em seu livro Mitologias ${ }^{22}$ cunhou a expressão linguagem intransitiva, fazendo uma distinção entre linguagem transitiva e intransitiva.

Linguagem intransitiva é aquela em que o autor usa a palavra como instrumento para falar sobre alguma coisa. A linguagem transitiva, diz Barthes, fala a coisa. Ele

${ }^{22}$. BARTHES, 1981. 
compara a linguagem intransitiva com o trabalho do marceneiro que usa a madeira para fazer uma cadeira. Este trabalha com a madeira. O escultor, que trabalha $a$ madeira, tem a linguagem transitiva, transformando a madeira em estátua. Esta definição poderia darnos a impressão de que lidamos com a diferença entre artesanato e arte. Para os fins deste trabalho gostaria de acrescentar algumas características sobre a linguagem transitiva e intransitiva.

Optei por utilizar a definição de linguagem intransitiva para as formas estatizantes, imobilistas, substitutivas de usos ativos e funcionais da linguagem. Quando o autor abusa de emprego de:

- verbos de estado (em vez de verbos de ação);

- frases nominais (também no lugar da ação);

- artigos e pronomes indefinidos;

- modalizadores;

- adjetivos intensificadores que não acrescentam um sentido novo ao que é contado;

- conectivos conclusivos, como enfim, portanto, assim, pois, sem relação com :

- uma ação (na realidade inexistente, ainda que pressuposta como tal);

- com um pensamento lógico - igualmente inexistente.

- O resultado destes usos é uma linguagem parada, vaga, imprecisa, proveniente da absorção de mitificações, mas que, não tendo intenção mitificante, apenas generaliza e mesmo imobiliza o mundo da/ e a narrativa.

Em contrapartida, a linguagem transitiva é uma linguagem de ação, dinâmica, em que precisão e imprecisão têm função relevante. Ação e movimento são duas características fundamentais da linguagem transitiva.

$\mathrm{O}$ uso da linguagem intransitiva indica desconhecimento ou insegurança no uso da palavra, estruturas, formas. Apenas descreve, quase que em tom de ladainha:

Falando-se de avô, figura de idade mais acentuada, boa, meiga e que quer a atenção geral da família, sentindo-se alvo de todos, enfim é uma criança vivida.

O trajeto de minha casa ao local de trabalho, faço-o de carro. Este trajeto é coberto em três minutos mais ou menos. (A precisão dos 3 minutos é modalizada por "mais ou menos").

Dois moços de 17 anos foram a casa de um senhor agiota, bem rico.

Foram para um acerto de contas. Conversaram, conversaram, mas não se entenderam. 
O resultado foi o seguinte: os dois moços roubaram o agiota e ainda cravaram-no de facas. (Em vez de facadas. Note que se trata de uma descrição, congelada, parada).

O distanciamento decorrente já não é o do narrador, mas do autor. E este corresponde a um distanciamento anestésico - da realidade, ou de si mesmo? Trata-se de uma linguagem que serve para transmitir aquilo que foi previamente proposto como verdade. Como, contudo, não se trata da verdade do autor do texto, sua resistência inconsciente o leva a congelar a ação, modalizada e desprovida de suspense.

O problema destas redações não reside na tentativa de transposição da oralidade para a escrita, mas na dificuldade e manifestar uma visão de mundo pessoal, impedida pela baixa auto-estima, efeito do 'mito do oprimido'. Distingue-se da forma simples do mito primitivo ou grego, na medida em que não consegue trabalhar com uma simbologia universal e não discerne o tema mítico (explicação de um fenômeno da natureza física do mundo, ou da natureza psíquica do ser humano). Substitui estes temas por temas de um quotidiano esvaziado de sentido, pela desqualificação do valor das próprias observações, emoções, pontos de vista. É bom ter clareza de que este esvaziamento não é absoluto, nem definitivo. Permanece sempre uma região de resistência, que pode ser ativada por estímulos diversos e que, em dadas circunstâncias, explica a mudança qualitativa da produção e do pensamento de uma mesma pessoa, de um momento a outro, como por milagre. E ainda, verifiquei que os processos de mudança se dão em surdina. São processo interior, portanto impossível de ser acompanhado. Os saltos qualitativos correspondem a momentos de revelação do processo. Por isto os processos de aprendizagem, ou de transformação, só podem ser percebidos a médio e longo prazo.

\section{Oralidade e escrita nas redações de alunos.}

A criança que nunca conheci, mas cuja cópia me foi encaminhada e que, segundo sua professora, "Não escreve certo quando copia. Quando escreve livremente (composição) o escrito tem sentido e escreve mais corretamente" fez uma cópia que me perturbou.

Rodrigo Artacho, de presumíveis 8 ou 9 anos, aluno de escola municipal de Campinas em 1984, deveria copiar - da lousa - o texto referido em nota ${ }^{23}$ :

$23 \quad$ O palhaço Cocadinha

Cocadinha é um palhaço muito alegre e engraçado.

Ele tem este nome porque pinta o rosto totalmente de branco.

É a figura mais procurada do Circo Rapadura. Seus grandes admiradores são as crianças.

Quando Cocadinha entra no picadeiro, dirigindo seu patinete vermelho a garotada grita:

- Cocadinha! Cocadinha! 


\section{Rodrigo copiou o seguinte:}

Cocadinha é um palhaço muito encaba

Ele tar esta porque pinta no ele tanta queria

e ficou com medo

Quando eu tinha tina era Salomão irmão quer ser ele ama ideia ideia com seu Eu quero dar o e o me teu (ou eu?) quero amor e o querido amor e o que e o quis e e o queria a festa e o am e o que se o moros.

Quando li o texto acima fiquei, inicialmente, deprimida, por tristeza pela criança - e talvez por decepção, já que minha hipótese é, era, será, que o ser humano tem virtualidades que precisam ser estimuladas para levá-lo a um desenvolvimento pleno (podendo variar os níveis de plenitude, ou de realização).

Num segundo momento decidi estudar o texto. Isolando os blocos diferentes do texto original - e compreensíveis para mim, temos:

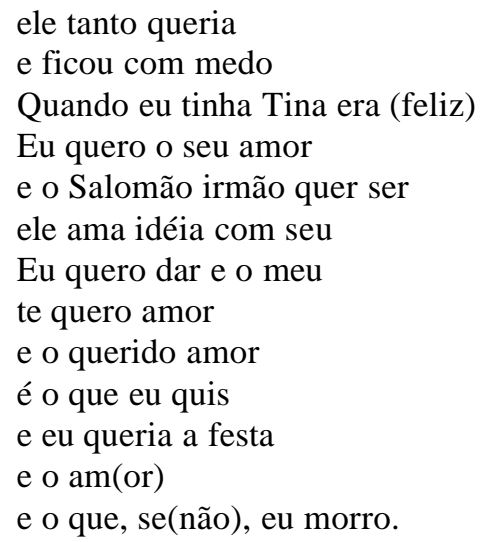

O comentário da professora confirma que a criança está alfabetizada. O que manifesta a cópia acima não tem relação com a interferência da oralidade na escrita, mas com a interferência da psique na escrita. É um ato falho, decorrente do desinteresse diante de uma tarefa tão aborrecida como uma cópia da lousa, em sala de aula. Rodrigo brada a sua carência afetiva, sua fome de amor e fraternidade, tão grande que, caso contrário, ele morrerá. O sofrimento e as carências do estudante interferem na qualidade de seu desempenho e seriam equivocadamente analisados como problemas do ensino.

Como nos textos produzidos por adultos, também as crianças revelam os seus sofrimentos psíquicos. Não se vá pensar, por extensão, que a forma de cuidar destes casos é obrigatoriamente e só a via da psicanálise. As atitudes docentes podem bastar para orientar este aluno a produzir textos diferentes - isto é, a encontrar um espaço de expressão competente, gratificante e talvez até mesmo reguladora de aspectos internos. À maneira de Galaaz, quando se dirige ao rei pescador para perguntar-lhe como está, o que tem, em vez de perguntar onde está o cálice sagrado, talvez baste manifestar interesse pela criança - não pela sua cópia, ou redação...

E a lona quase vem abaixo de tantos aplausos.

Cocadinha é preferido entre os palhaços porque é mágico. Ele faz mágicas e travessuras pois suas apresentações acabam sempre em confusão e grandes risadas.

Como é engraçado o palhaço Cocadinha. 
Note-se que o texto que sobra, aquele que descasquei da pseudo cópia, é poético. Revela sensibilidade, inclusive para a palavra. Talvez a frase certa corresponda a desvendar o poema sob o texto.

(Quando os casos de incompreensão do texto escrito são excessivamente gritantes, o problema pode não ser de mera explicitação das idéias e sentimentos do seu autor, mas de alfabetização incompleta. O procedimento orientador será alfabetizar, tão simplesmente. Mas mesmo a alfabetização se beneficia da relação fala-escrita. Conversar com o aluno é atitude fundamental. E a aprendizagem da escrita se beneficia da consciência de que ela é imagem, de que o aluno precisa ver muitas ocorrências de escrita, tanto de palavras, como de textos. E passar adiante na aprendizagem, quando alguém empaca diante de uma dificuldade, não ajudará à superação da dificuldade).

As respostas na produção de textos de crianças, adolescentes e adultos revelam o lado "escravo" 24 daqueles que não tiveram estrutura para enfrentar a insídia ideológica das formas de poder. O "erro" manifesta-se na incompletude das utilizações das formas que poderiam estar disponíveis, mas que foram desprezadas pela escola. Porque as formas simples são ficcionais, e a escola teme trabalhar com ficção - pelo menos a partir da década de 70 e até o fim do séc. XX. O espaço para a expressão poética ou de ficção em prosa pode garantir um território de elaboração de conflitos.

\section{A leitura das redações}

Com relação à leitura, o princípio nos indica que a produtividade do ato de compreensão da palavra alheia, do texto que o nosso aluno lê, está diretamente ligada à capacidade do professor de reconstruir os determinantes contextuais - contexto histórico imediato ou distante, situação do autor nesse contexto (seus valores), influências estilísticas e/ou ideológicas do autor ou dos autores etc. - geradores do texto, cobrindoo com questões pertinentes que busquem explorar aqueles aspectos que uma leitura superficial normalmente deixa escapar.

Em suma, uma boa leitura de qualquer texto, oral ou escrito, tem de ser capaz de preencher os interstícios e os implícitos indicados pelo texto, reconstruindo dessa forma o referencial amplo do dizer do autor. Esse é o primeiro passo na direção de uma possibilidade valorativa do aluno em relação ao seu texto. A meu ver, esse deve ser um dos grandes objetivos do trabalho de leitura, uma vez que o exercício de confronto com a palavra do outro é um fator preponderante na formação da subjetividade discursiva do nosso aluno. Incluir-me, seja eu ouvinte em encontro de interlocutores, seja eu docente ou aluna, leva-me a uma atitude includente: eu sou o outro. Eu mesma como outro são palavras de Paul Ricoeur. Sim, os sinos dobram por mim.

\footnotetext{
${ }^{24}$ Cf. DELEUZE, Gilles. Cours de Vincennes "Spinoza / Nietzsche"- Décembre 1980 (fragments) http://www.webdeleuze.com/TXT/frag_spin_80.html.
} 